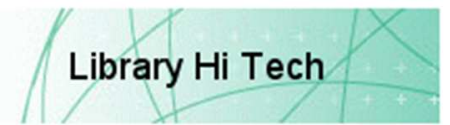

\title{
Promoting Information Literacy: Perspectives from UK Universities
}

\begin{tabular}{|r|l|}
\hline Journal: & Library Hi Tech \\
\hline Manuscript ID & LHT-10-2016-0118 \\
\hline Manuscript Type: & Original Article \\
\hline Keywords: & $\begin{array}{l}\text { Information literacy, Academic libraries, Universities, Library instruction, } \\
\text { Website promotion, Strategic management }\end{array}$ \\
\hline \multicolumn{2}{|c}{} \\
\hline
\end{tabular}

\section{SCHOLARONE \\ Manuscripts}




\title{
Promoting Information Literacy: Perspectives from UK Universities
}

\begin{abstract}
Purpose - Academic libraries have sought to become the leaders in the provision of information literacy (IL). This study seeks to identify to what extent IL is being promoted through institutional websites.

Design/methodology/approach - Data was collected from all UK university websites $(n=133)$ in early 2015 to identify the promotion of IL. Content analysis was used for the five categories: IL in the mission statement, visions or strategic plan; IL model or framework; IL policy; IL assessment; and, IL training. Data collection was limited to information in the public domain which could be accessed from individual websites, which were searched and browsed systematically.

Findings - $85.7 \%$ of universities promote IL to some extent on their websites in at least one of the five categories, however the degree of the information provided varied extensively. Less than $6 \%$ of universities promote IL at institutional level. Only $17.3 \%$ refer to a model or framework, $15.8 \%$ show their IL policy and 9\% provide information on their assessment of students' IL skills. Information on IL training is offered on $84.2 \%$ of websites, the most common method being online tutorials, although $52.6 \%$ only offer training for one or two aspects of IL, primarily information seeking and citing and referencing.

Originality/value - This article provides up-to-date data concerning how universities in the UK promote information literacy in the public domain via their websites. It should be of interest to academic librarians who are responsible for IL provision.
\end{abstract}

Keywords Information literacy, Academic libraries, Universities, Website promotion, Library instruction

Paper type Research paper 


\section{Introduction}

Over recent decades, university libraries have sought to position themselves as the providers of information literacy (IL) training (Chen and Lin, 2011; Webber and Johnston, 2006), in acknowledgement of the increasing need for students to learn how to search for, evaluate and use information in their studies, and subsequently, in their working lives (Shenton and Fitzgibbons, 2010). The profession has viewed IL as a key component of digital literacy (Belshaw, 2011) and its role in promoting IL has been central to the relevance of libraries and librarians in a digital age. Hence, an important question is the extent to which university libraries visibly promote their IL programmes and other activities via the main avenue through which student's access library services and resources, the university and university library website, given the finding from the Educause Center for Analysis and Research (ECAR) that ' $88 \%$ of students use their institution's website regularly' $(2011$, p.5).

Over a decade ago, Corrall (2005) undertook a study that responded to the question: 'What evidence exists of a strategic commitment to IL?' She found that although there was some evidence of engagement in seventy-five institutions, there were neglected areas, specifically the lack of 'explicit commitments to IL in formal mission statements' from libraries. She also established that IL within strategic agendas was extremely weak and representation was required particularly to 'raise awareness, formalise strategies, mobilise resources and advance plans for taking substantial steps towards the information literate university'. It is timely to revisit and expand consideration of the extent to which academic libraries engage in promoting IL to key constituencies, and through the important channels of university and library websites.

The term information literacy was first defined as being able to find information (Zurkowski, 1974). Since then many attempts have been made to elaborate on this simple definition of IL, all of which highlight the critical evaluative skills involved in the process of finding and using information. The Chartered Institute for Librarians and Information Professionals (CILIP) define IL on their website as "knowing when and why you need information, where to find it, and how to evaluate, use and communicate it in an ethical manner'. In addition to this definition, CILIP detail a list of skills which are required for an individual to become information literate.

Going beyond definitions, The Association of College and Research Libraries (ACRL) produced the IL Competency Standards for Higher Education (HE) which were endorsed by 
the American Association for Higher Education (October 1999) and by the Council of Independent Colleges (February 2004). These were implemented across America, with HE institutions responsible for ensuring that their students are information literate and are able to transfer those skills into the workplace and become lifelong learners. During the fifteen years since the publication of the Standards, academic librarians and HE institutions in America have developed tools and resources which have allowed IL to be integrated into the curricula, and encouraged librarians to look at their teaching and learning practices (Ariew, 2014). 'The Standards helped many institutions to re-think their mission, re-evaluate their programs, and communicate more clearly to academic faculty and administrators the value of IL instruction. Because of the Standards, IL was not just a nice notion a few institutions and experts embraced; it became an important movement in changing the paradigm for academic libraries' (Ariew, 2014, p.215). Due to a rapidly changing environment, The Framework for Information Literacy for Higher Education was adopted by the ACRL Board in January 2016 and the IL Competency Standards were rescinded in June 2016, the belief being that information literacy as an educational reform movement will realize its potential only through a richer, more complex set of core ideas' (American Library Association (ALA), 2016). The transition for HE institutions to the Framework is currently in progress and is expected to be complete by July 2017.

In the UK, the situation for implementation of IL instruction is different in that whilst there exist several IL models, such as 'The Seven Pillars' from the Society of College, National and University Libraries (SCONUL), there is no one model that has been endorsed to become the definitive standard that must be achieved by all HE institutions.

There is a significant body of work on the IL strategies and activities of academic libraries, covering institutional commitment to IL (Bent et al., 2006; McKinney et al., 2011), the use of models or frameworks, policies and assessment (Walsh, 2009; Stubbings and Franklin, 2005), and the extent and nature of training (Bent et al., 2006, Madden, 2014). However, most of these studies are based on one university. Exceptions are studies by the Research Information Network (2008) and Corrall (2005). The Research Information Network undertook a study called 'Mind the skills gap: Information-handling training for researchers. Complementing this study, Corrall (2005) analysed key documents, including mission statements, visions and strategic plans relating to IL on university websites. 
Hence, acknowledging the potential importance of IL to the role and perceptions of university libraries, this article aims to contribute to knowledge regarding the promotion of IL by UK universities. Specifically, in the context of university websites, it will:

(1) Identify the level of university commitment to IL.

(2) Explore the extent of reference to models, policies and assessment.

(3) Profile the information provided on the nature and extent of training.

(4) Investigate the relationship between IL promotion and student satisfaction with the library service.

The next section offers a brief literature review followed by the outline of the methodology for this study, before the findings are reported. The results illustrate what is publically available on individual websites, therefore anything which would only be available to staff or students once they are logged in to their institutions site will not be included in the findings as the authors were unable to access and review it. The article concludes with a discussion of the findings and conclusions and recommendations.

\section{Literature Review}

\section{Policy context}

In 2009, the United Nations Educational, Scientific and Cultural Organization's (UNESCO) Information for All Programme (IFAP) endorsed IL as a basic human right. They asserted that 'IL skills are necessary for people to be effective lifelong learners and to contribute in knowledge societies' (UNESCO, 2009, p3). In the UK, the Library and Information Commission (LIC), in 'Keystone for the Information Age', makes the case for a national information policy for the UK, with 'developing universal information literacy' being identified among the issues as needing to be addressed.

\section{University commitment to IL.}

Previous research consistently raises the concern that the implementation, practice and development of IL is often hindered due to a lack of recognition of the vocabulary used (Research Information Network, 2008; Virkus and Mandre, 2015). IL is a term which is owned and recognised by library and information service (LIS) professionals but not necessarily by academics or university management. Indeed, there is some scepticism as to its importance (Bawden and Robinson, 2009). In addition, there is often a confusion 
between IL skills and information technology (IT) skills amongst academics and students. This fuels the assumption that because people are adept in using IT, they can deem 'themselves competent and skilful when dealing with information' (Koltay et al., 2015, p.88). In turn, this 'disguises the unsatisfactory [IL] levels amongst the general population' (Herman and Nicholas, 2010, p.249).

Virkus and Mandres (2015) found that commitment from leaders and managers is necessary at all levels within a university (top management level, library level, school and faculty level, department level and programme level) to ensure the success of IL. Lau (2006, p.20) agrees that for an IL programme to be successful, it needs a 'commitment at the institutional level'. Others share this belief but also add that for a university to be truly information literate, it 'requires that all members - administrators, academics and researchers, as well as students - become information literate' (Webber and Johnston, 2003, p.102).

McGuinness (2003, p.246) argues that strategic plans and missions 'offer a useful means of establishing the library's commitment to IL, or information skills programmes', and that this documentation should appear on university websites in the public domain.

\section{IL models, policies and assessment.}

'The view that collaboration between library, faculty and administrative staff is crucial to ensure the development of a coherent IL policy in any institution is fully promoted' by a model (Andretta, 2005, p.41). Within the UK there are a variety of models and frameworks which have been adopted by academic institutions. The IL website, run by the CILIP Special Interest Group, identifies the main models and frameworks developed for use in the UK as: CILIP Information Literacy Model; SCONUL Seven Pillars of Information Literacy; A New Curriculum for Information Literacy (ANCIL); National Information Literacy Framework (Scotland) and National Information Literacy Framework (Wales).

Table 1 compares the four IL frameworks developed by ANCIL, CILIP, SCONUL and ACRL (the American IL Framework). 


\begin{tabular}{|c|c|c|c|c|c|c|c|}
\hline \multicolumn{2}{|c|}{ ANCIL } & \multicolumn{2}{|c|}{ CILIP } & \multicolumn{2}{|c|}{ SCONUL } & \multicolumn{2}{|c|}{ ACRL } \\
\hline 1 & $\begin{array}{l}\text { Transition from } \\
\text { school to HE }\end{array}$ & 1 & $\begin{array}{l}\text { A need for } \\
\text { information }\end{array}$ & 1 & $\begin{array}{l}\text { Identify a personal } \\
\text { need for information }\end{array}$ & 1 & $\begin{array}{l}\text { Authority is } \\
\text { Constructed } \\
\text { and } \\
\text { Contextual }\end{array}$ \\
\hline 2 & $\begin{array}{l}\text { Becoming an } \\
\text { independent } \\
\text { learner }\end{array}$ & 2 & $\begin{array}{l}\text { The } \\
\text { resources } \\
\text { available }\end{array}$ & 2 & $\begin{array}{l}\text { Can assess current } \\
\text { knowledge and } \\
\text { identify gaps }\end{array}$ & 2 & $\begin{array}{l}\text { Information } \\
\text { Creation as a } \\
\text { Process }\end{array}$ \\
\hline 3 & $\begin{array}{l}\text { Developing } \\
\text { academic literacies }\end{array}$ & 3 & $\begin{array}{l}\text { How to find } \\
\text { information }\end{array}$ & 3 & $\begin{array}{l}\text { Can construct } \\
\text { strategies for locating } \\
\text { information and data }\end{array}$ & 3 & $\begin{array}{l}\text { Information } \\
\text { has Value }\end{array}$ \\
\hline 4 & $\begin{array}{l}\text { Mapping and } \\
\text { evaluating the } \\
\text { information } \\
\text { landscape }\end{array}$ & 4 & $\begin{array}{l}\text { The need to } \\
\text { evaluate } \\
\text { results }\end{array}$ & 4 & $\begin{array}{l}\text { Can locate and access } \\
\text { the information and } \\
\text { data they need }\end{array}$ & 4 & $\begin{array}{l}\text { Research as } \\
\text { Inquiry }\end{array}$ \\
\hline 5 & $\begin{array}{l}\text { Resource discovery } \\
\text { in your discipline }\end{array}$ & 5 & $\begin{array}{l}\text { To work with } \\
\text { or exploit } \\
\text { results }\end{array}$ & 5 & $\begin{array}{l}\text { Can review the } \\
\text { research process and } \\
\text { compare and } \\
\text { evaluate information } \\
\text { and data }\end{array}$ & 5 & $\begin{array}{l}\text { Scholarship } \\
\text { as } \\
\text { Conversation }\end{array}$ \\
\hline 6 & $\begin{array}{l}\text { Managing } \\
\text { information }\end{array}$ & 6 & $\begin{array}{l}\text { The ethics } \\
\text { and } \\
\text { responsibility } \\
\text { of use }\end{array}$ & 6 & $\begin{array}{l}\text { Can organise } \\
\text { information } \\
\text { professionally and } \\
\text { ethically }\end{array}$ & 6 & $\begin{array}{l}\text { Searching as } \\
\text { Strategic } \\
\text { Exploration }\end{array}$ \\
\hline 7 & $\begin{array}{l}\text { Ethical dimension } \\
\text { of information }\end{array}$ & 7 & $\begin{array}{l}\text { How to } \\
\text { communicate } \\
\text { or share } \\
\text { findings }\end{array}$ & 7 & $\begin{array}{l}\text { Can apply the } \\
\text { knowledge gained: } \\
\text { presenting results, } \\
\text { synthesising new and } \\
\text { old data to create } \\
\text { new knowledge and } \\
\text { disseminate it in a } \\
\text { variety of ways }\end{array}$ & & \\
\hline 8 & $\begin{array}{l}\text { Presenting and } \\
\text { communicating } \\
\text { knowledge }\end{array}$ & 8 & $\begin{array}{l}\text { How to } \\
\text { manage the } \\
\text { findings }\end{array}$ & & & & \\
\hline 9 & $\begin{array}{l}\text { Synthesising } \\
\text { information and } \\
\text { creating new } \\
\text { knowledge }\end{array}$ & & & & & & \\
\hline 10 & $\begin{array}{l}\text { Social dimension of } \\
\text { information }\end{array}$ & & & & & & \\
\hline
\end{tabular}

Table 1: Summary of four information literacy models 
With the exception of CILIP's, every model has been updated in recent years to reflect the changing $\mathrm{HE}$ environment and to allow for a holistic and flexible process which is integral to learning. In addition to the skills outlined in Table 1 guidelines are published for each model to enable practitioners to create institutional IL policies, design IL programmes and adapt the guidelines to fit with the individual institution. In 2013, Martin analysed the four British IL models and compared them against the ACRL Standards; this has not been repeated with the updated ACRL Standards.

Initially the models appear to be similar in the respect that an information need is recognised, followed by finding the information and then evaluating it and presenting it. This fluid flow through the skills which is apparent in the British models doesn't exist in the ACRL Framework, where there are very distinctive crossovers between each of the six concepts, which is why they are not presented in a specific order but are in an alphabetised list. The new ACRL framework is essentially 'a cluster of core concepts, with flexible options for implementation, rather than a set of standards or learning outcomes'. 'At the heart of this Framework are conceptual understandings that organize many other concepts and ideas about information, research and scholarship into a coherent whole' (ALA, 2016).

The closest overlap exists between the models offered by CILIP and SCONUL, however the Seven Pillars model was 'revised and extended to reflect more clearly the range of different terminologies and concepts that have come to characterise IL' (Goldstein, 2015, p.2) when a survey conducted by Gallacher in 2009, identified the shortcomings of the model within HE institutions. The results of the survey showed that 40 institutions out of the 52 respondents were using the Seven Pillars model. It was identified that many professionals felt that the original SCONUL model was too 'library-centric' and that 'IL frameworks in general were felt to be too focussed on an enumeration of skills' (Andretta, 2006, p.12). Thus, SCONUL made an important innovation to their model through adopting a series of 'specialist lenses that reflect context-driven perspectives and needs of different categories of users'. Five lenses have been created: 'research, digital literacy, open educational resources, evidence-based practice healthcare and, most recently, graduate employability' (Goldstein, 2015, p.2).

The ANCIL curriculum aims to go a step further and create what they 'believe to be a continuum of skills, competencies, behaviours and attitudes ranging from functional skills to intellectual operations that together comprise the spectrum of information literacy' (Secker 
and Coonan, 2011, p.4). In addition to the other frameworks discussed here, the model recognises the transition period from school, and later the need to develop skills to become an independent learner in the workplace. This is in response to Hepworth and Walton (2009, p.4) who argued that some existing models, including SCONULs, were 'overly rigid and fail to take into account the interactive nature of dealing with information. They argued that becoming information literate needs to be viewed from the perspective of an individual completing a task in a given context, which involves interplay of behavioural, cognitive, metacognitive and affective states, and that contextual interplay is not reflected in existing models'.

Town (2003, p.53) claimed that recognition is required between those who are information literate and those who are not when defining IL and that 'measurement is key to the usefulness of IL as a concept'. Griffiths and Glass (2011) assessed undergraduate students at Manchester Metropolitan University (MMU) using the online IL Test from Steven Wise, Lynne Cameron and their team at the Institute for Computer-Based Assessment, James Madison University (JMU), Virginia, USA (Wise et al., 2005). As part of their conclusions and recommendations they suggest that a UK test be devised and mention that an IL Question Bank is under discussion. However, the extent of the use of such a question bank for the assessment of IL, or its development as an instrument for universal testing, is not known. Yet it is generally accepted that without the ability to measure the effect of IL training programmes, the 'value of them will remain uncertain and arguable' (Town, 2003, p.62). Webber and Johnston (2003, p.106) also recognised that when assessment is taking place, 'it is not necessarily being fed back to the student' which results in them being unable to 'identify ways to improve or gain an insight into their level of attainment'.

\section{IL training.}

Previous research suggests that rather than training being developed around an institutions IL policy which is derived from a model or framework and would therefore target the many skills required to become information literate, many universities are focussing predominantly on information seeking (Research Information Network, 2008). It has been suggested that this is due to faculty perceiving the librarians who deliver training sessions, as only being experts in this particular area Godwin (2003, p.90). He also states 
that the 'transformation will come when these [IL] skills are seen as an essential part of the curriculum and not an optional extra'.

In addition to this, students regard sessions as unnecessary because they believe their information seeking and evaluation skills are better than they actually are (Gross and Latham, 2012; Smith et al., 2013). Many students only see the benefit of training outside the curriculum if endorsed by their course leaders or if it is credit bearing (McGuiness, 2003). Saunders (2012) research found that there is an ad-hoc approach to IL training which is that training is delivered to students as cramming sessions which have been found to be highly insufficient (Mery et al., 2012; Grassian and Kaplowitz, 2009). Research suggests these are the reasons why IL 'programs should be embedded in the curriculum' (Wang, 2011; Chen and Lin, 2011, p.165).

\section{IL promotion and student satisfaction with the library service.}

When considering the relationship between IL and student satisfaction, Haddow (2013) discovered that the academic library's role is given little or no attention. The UK national survey which is administered annually and assesses student satisfaction and engagement with their university, asks only one question regarding satisfaction level with the library: 'The library resources and services are good enough for my needs' (Higher Education Funding Council for England, 2010, p.23). in addition, when answering this, Kuh and Gonyea (2003, p.266) suggest that students do not link IL directly with their library experience. The accuracy of the score awarded could also be debated in the light of Goodall and Pattern's (2011, p.166) research which identified that ' $47 \%$ of students are not borrowing from the library' and 'nearly $39 \%$ are not accessing electronic resources'.

With these findings from previous research in mind, the authors will seek to identify whether any relationship exists between the library score awarded in The Times Higher Education (THE) Survey Experience Survey and the IL content on individual university websites.

\section{Methodology}

Content analysis of university websites was conducted. This approach was chosen because it 'is an approach to the analysis of documents and texts that seeks to quantify content in terms of predetermined categories and in a systematic and replicable manner' 
(Bryman and Bell, 2015). In this study content analysis provides a clear picture of the IL message which is portrayed to students, academics, university managers and other audiences, and allows data to be collected from every university.

Data was collected from the websites of the 133 universities in the UK, identified from the Universities UK website, during a three-month period in early 2015. The research commenced with a pilot study based on a random selection of ten universities. This involved a thorough exploration of the websites in their entirety to ascertain the likely locations in which data relating to IL would be found. From the ten websites it was identified that IL was included in key documents and policies, such as strategic plans and teaching and learning policies as well as in mission statements and visions. Some websites stated which model(s) or framework(s) they used. Specific IL policies were located on several sites. On most of the ten websites there was some form of IL training promoted and mention of an assessment on one site. This meant that five key categories emerged from the pilot study; these were used as the themes that guided the content analysis. They are: IL in the mission statement, visions or strategic plan; IL model or framework; IL policy; IL assessment and IL training.

The coding schedule and manual were created (Appendix 1 ) as a result of the pilot study. The remainder of the university websites were examined and the data resulting from this was transferred into the software program SPSS Statistics 22 for analysis. Coding was conducted by the primary researcher. Cross checking was undertaken by two other researchers in order to eliminate subjectivity.

Throughout the process the researchers were mindful of the fact that data could appear in different locations on individual websites, so for each website the site map was consulted in addition to checking what were identified as the most common places for published data during the pilot study. The researchers also completed terminology searches using the search facility for each website in an attempt to ensure nothing was overlooked.

The process for finding any information relating to IL model(s) and an IL policy was noted and details of both its exact site location and the navigation through the website to locate it were recorded. Screenshots of the pages were taken when anything relating to these were found. This methodical approach would allow the researchers to identify the prominence of the information relating to the IL model(s) and policy on the website and ascertain the importance it is given when promoted. The purpose of collecting data in this format meant 
that the authors were able to use the data collected on the prominence of the information displayed to assess the university and library commitment to IL.

Also when data was detected on each website, in addition to coding it, screenshots were captured and key documents downloaded and saved that would provide detailed reference records of the content of the website at the time of data collection. Keeping records of this description also allowed the researcher to collect further data independent of the coding for further studies, such as which IL model was being used.

\section{Findings}

The data collected from the 133 university websites has been collated and will be presented in various formats within this section. 114 (85.7\%) universities promote IL to some extent on their websites in at least one the five categories stipulated for this study.

\section{University commitment to IL.}

The authors sought to identify if the level of commitment to IL within universities could be identified from the information on websites. As discussed earlier, IL programmes have the potential to be more successful if they are promoted and supported at institutional level. Seven universities (5.3\%) have included IL in the mission statement, visions or the strategic plan for the entire university. $30.8 \%$ (41) universities have included IL in the library's mission statement, visions, strategic plan or key performance indicators (KPIs).

In addition to these findings, Figure 1 shows whether the information relating to the IL model(s) used and the IL policy were displayed within website pages which promote the university library or those which promote the whole university.

The authors quantified the prominence of the information relating to the IL models and policies on the website (Appendix 1), so regardless of where the information appeared on the website, a decision was made as to whether it is noticeable towards the top of website pages with relatively few mouse clicks to locate it, or if it is hidden within the site and could only be found by: conducting specific searches, having to navigate through the site with many mouse clicks or if it has been added to the bottom of pages with little importance.

After coding, the findings revealed that of the 23 universities who use a model, $47.8 \%$ (11) of them promote this prominently on their website, and for the 21 universities who have created an IL policy, $61.9 \%$ (13) have this as a downloadable document in a prominent 
site location. It is also worth noting that 7 (5.3\%) universities who promote that they use a specific IL model and have created an IL policy are displaying both in prominent places.

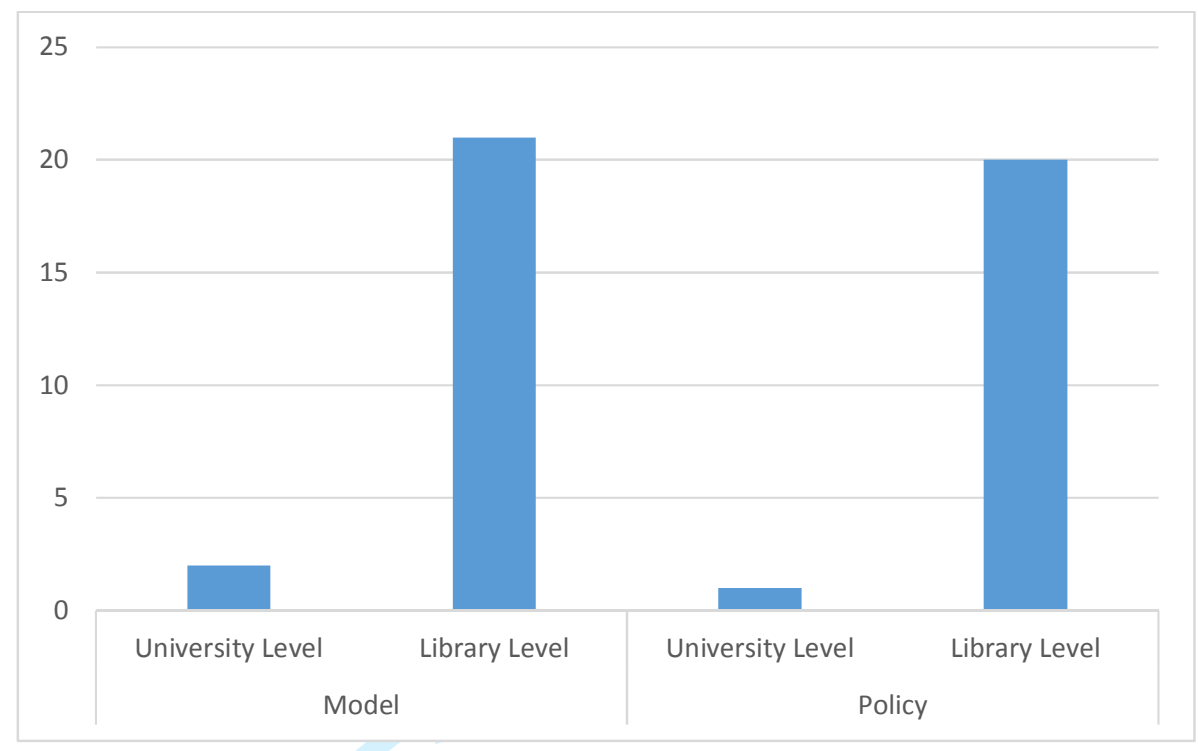

Figure 1: Website location of the IL model and policy information

\section{Models, policies and assessments.}

Figure 2 illustrates the use of specific IL models by universities within the UK. Of the 133 universities, $23(17.3 \%)$ advertise that they use one or more of the universal models or have created their own. The most used model is the Seven Pillars of Information Literacy by SCONUL.

Within the library pages of the other 110 university websites, the authors discovered instances where several or all of the various IL models are presented, however this was in the context for the definition of IL and its purpose within a HE setting to be explained to the website user. Instances where this has occurred have not been included within the results unless the individual university specifically stated that they were using a particular model(s). In fact, only 9.8\% (13) universities actually define IL and explain its purpose and importance on their website.

$15.8 \%$ (21) of the universities have a specific IL policy, most of whom have this displayed or linked to, within the library pages of the website. One university had the policy included with other significant policies in the 'About Us' section of the website. 
1

2

3

4

5

6

7

8

9

10

11

12

13

14

15

16

17

18

19

20

21

22

23

24

25

26

27

28

29

30

31

32

33

34

35

36

37

38

39

40

41

42

43

44

45

46

47

48

49

50

51

52

53

54

55

56

57

58

59

60

Only 12 universities (9\%) state that their students undertake an IL assessment. Three of these websites discuss the assessment which takes place but the website user has to login to be able to access it, whereas the assessment can be seen publically on the other sites.

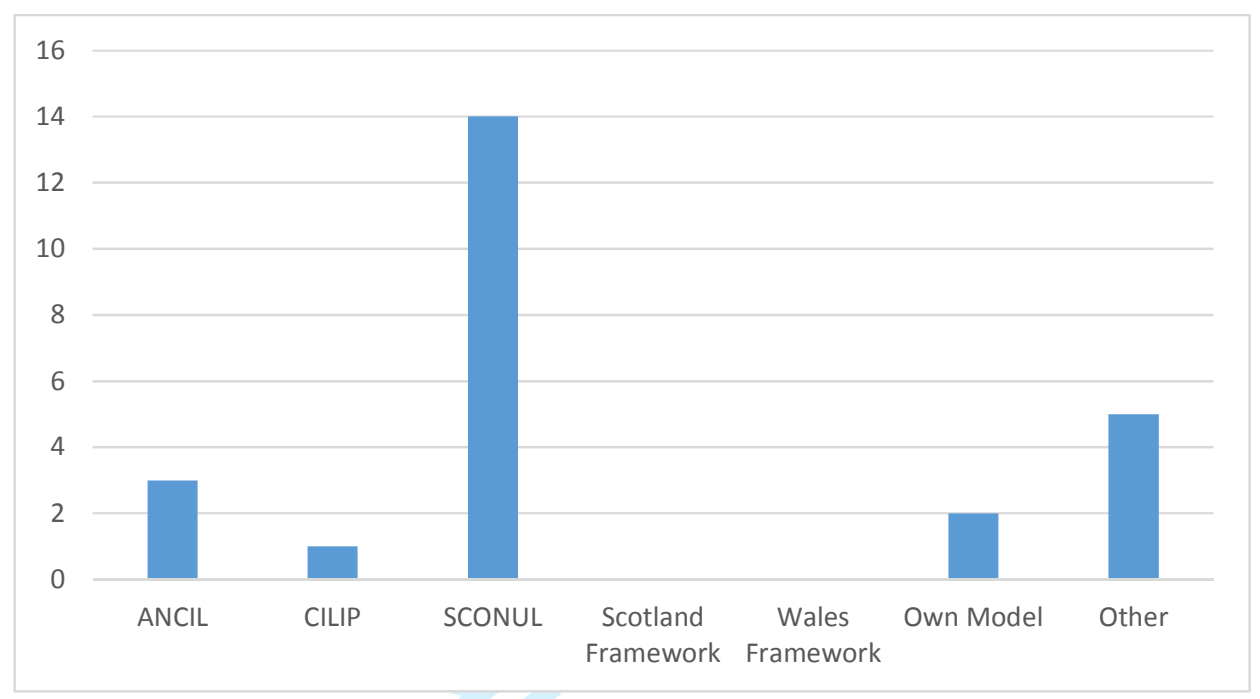

Figure 2: University use of information literacy models

\section{IL training.}

Of the 133 universities, only 21 (15.8\%) have no IL training promoted on their websites. The remainder promote the various IL training that is on offer, which takes many different forms and is made available for different groups within the institution as illustrated in Figure 3. The chart indicates that the majority of universities (82) are focussing on providing IL training for students only and 29 universities are offering it to both their students and staff.

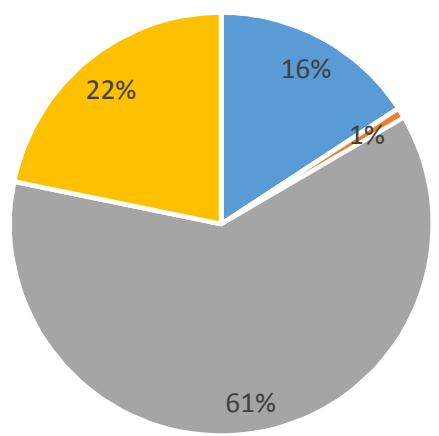

- No training available

- Training for staff only

- Training for students only

- Training for staff and students 
Figure 3: IL training availability

Figure 4 shows the type of IL training which is being promoted on the websites of the 112 universities that offer it. The most common forms of training promoted include online tutorials, librarian appointments and workshops.

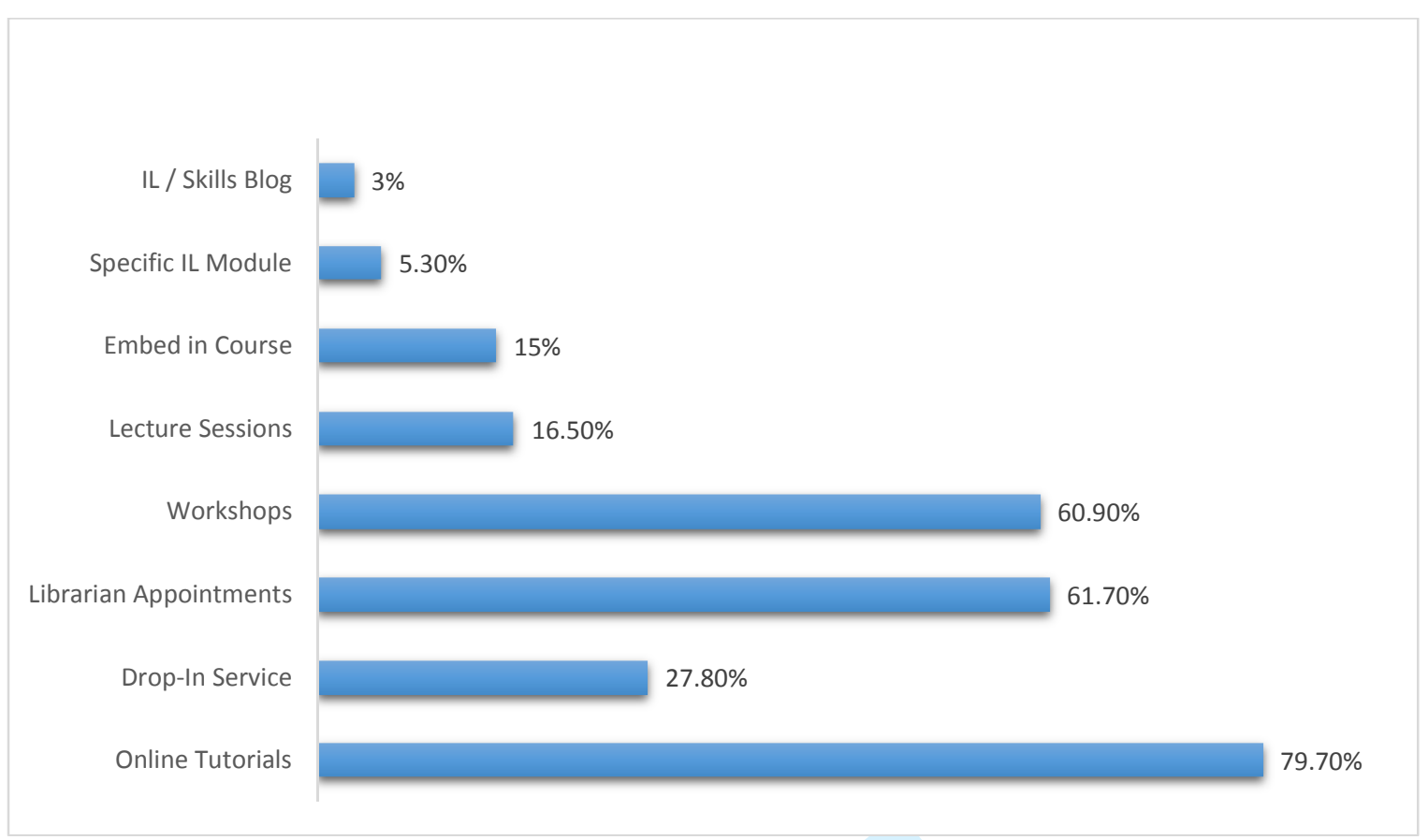

Figure 4: Type of IL training available within universities

As introduced in Table 1, to become information literate involves a wide skill set which would be developed through a combination of instruction and practice, so it was interesting to discover that only $36(27.1 \%)$ universities provide online tutorials for each set of skills. Of the $79.7 \%$ of universities which provide online tutorials, $52.6 \%$ (70) of them provide training for only one or two of the skills, which are predominantly information seeking and citing and referencing sources, which in the CILIP model would be 'How to find information' and 'The ethics and responsibility of use'. The same results emerge for the workshops promoted; of the 81 universities who provide workshops, $36.1 \%$ (48) are again focussing only on developing skills in search techniques, citation and referencing.

\section{IL promotion and student satisfaction with the library service.}


The THE Survey Experience Survey 2015 data was used as this correlated with the dates when the data was collected from the university websites. The average score awarded by students for 'Good library and library opening hours' in the THE Survey was plotted against the total website score for each university collected in this study. The score was derived from the Coding Manual as shown in Appendix 1. On this basis, the highest potential website score for a university is 19. Figure 5 shows the results in the form of a plotted graph with a trend line. Interestingly, the trend line shows that the higher the website score (those universities who are publically promoting their IL practice and commitment on their website), the least satisfied students are when they have rated 'Good library and library opening hours'. Table 2 shows the top ranking universities in the THE student satisfaction for the library score and those for the website score.

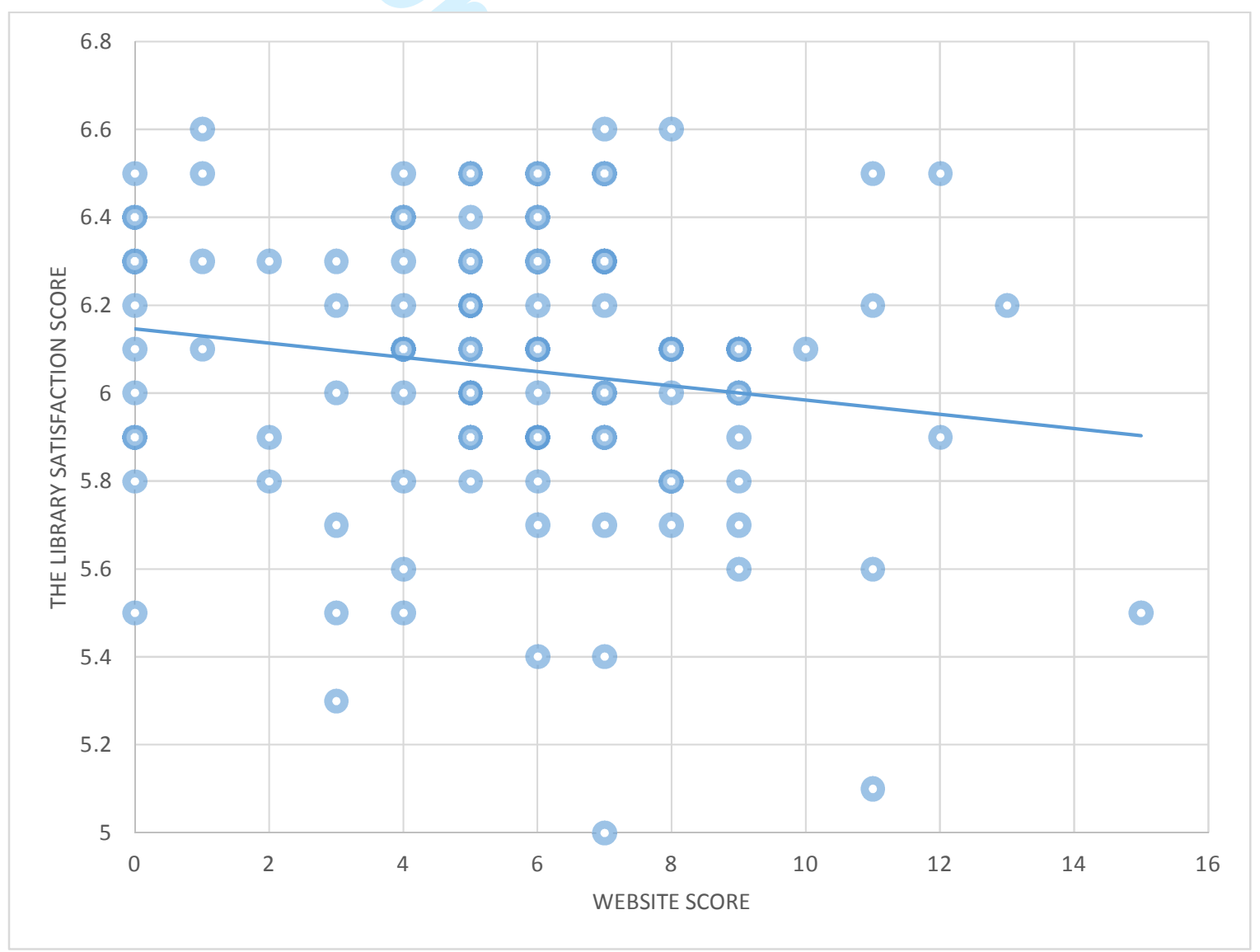

Figure 5: The 2015 Times Higher Education library satisfaction score v IL website score 


\begin{tabular}{|c|c|c|c|}
\hline \multicolumn{2}{|c|}{$\begin{array}{c}\text { Top Universities in THE Library Satisfaction } \\
\text { Score }\end{array}$} & \multicolumn{2}{|c|}{ Top Universities in the IL Website Score } \\
\hline University & Score & University & Score \\
\hline$=1$ University of Bath & 6.6. & 1 University of South Wales & 15 \\
\hline$=1$ University of Cambridge & 6.6 & 2 University of Leeds & 13 \\
\hline$=1$ Keele University & 6.6 & $=3$ University of Sheffield & 12 \\
\hline & & $=3$ Ulster University & 12 \\
\hline
\end{tabular}

Table 2: Top ranking universities in The Times Higher Education library satisfaction score and IL website score

\section{Discussion}

\section{University commitment to IL.}

The value of IL has been under scrutiny for many years. Stanley Wilder (2005) wrote an anti-IL article and claimed that developing effective IL programmes would require enormous and coordinated shifts in curricular emphases and resource allocation, none of which is either practical or politically realistic. William Badke (2014, p.69) stated that 'academia continues not to take us [librarians] seriously, and IL, a 'no brainer' to most of us, has had an exceedingly hard time getting itself lodged into HE even to its current level'. This leaves us in the situation where the library profession is embracing the importance of IL and faculty is criticising it, and an HE system which uses no universal standards or one specific IL model. It is therefore no surprise that the results show that only 7 of the 133 of universities are including IL at institutional level in mission statements, visions and strategic plans.

The results are more promising with 41 universities including IL in their library's mission statement, visions, strategic plan or KPIs, which means a total of $36.1 \%$ of UK universities have IL included within key documents which are visible to the public and therefore see IL as a central element of their strategy. This endorses previous studies (McGuiness, 2003) which have shown that IL has become the responsibility of the librarian, whose success relies 
heavily on the strength of the relationship between faculty and the library. However, this implies that it is not enough to have IL visible in the library's statement, but that the faculty's commitment must also be evident of the work of the library and all its departments in producing graduates with the knowledge and critical thinking skills for the workplace.

The discussion of the findings from this present study sets out to illuminate how such a vision of IL is currently achieved and promoted on UK university websites, focusing on the key aspects of IL, its models, policies, assessment and training, as well as its possible relationship to student satisfaction.

\section{Models, policies and assessment.}

This study shows that the use of models, policies and assessments by universities is very low. The most used model is The Seven Pillars of Information Literacy by SCONUL which was created after a Task Force were formed in 1998 with an initial brief to consider three questions:

- What do we mean by information skills?

- Why are they important?

- What constitutes best practice?

Stéphane Goldstein produced a report for SCONUL in 2015 and reflected on SCONUL's 2009 survey which 'demonstrated that the model has been put to practical use by academic librarians, notably for purposes such as underpinning the design of institutional IL programmes, serving as a basis for the development of policy and strategy, and devising institutional frameworks'. The survey (Gallacher, 2009) only reported on 40 universities. From the 133 UK universities in this study only 14 (10.5\%) are using the Seven Pillars model.

This would suggest a somewhat ad-hoc approach to IL by UK universities where, unlike in America, there is no universal IL model or framework which provides academic institutions with a directive to follow, create policy and IL programmes around and assess the IL capabilities of students. Indeed, in this study 21 universities have an IL policy, 8 (38.1\%) of those universities do not mention on their websites that they are using a model even though it is generally accepted that the IL policy is created from the model (Andretta, 2005). Policy support is not uniform in the UK (Corrall, 2007); in contrast, American and even Australian government publications identify IL skills as key competencies for the workplace and lifelong learning. 
The difference between America and the UK and relating to the use of a universal IL framework is also evident in the level of reference to IL assessment on UK universities websites. When IL has both credibility and value, through the use of a clear framework, the subsequent steps are to create an IL training programme and assessments which measure the effectiveness of the programme. James Madison University (JMU) requires hat all first year students were to pass the Information-Seeking Skills Test (ISST) to demonstrate competency; otherwise they were not permitted to continue with their academic studies (Cameron et al., 2007). In our study, 12 universities state on their website that their students undertake an IL assessment, but of those it is unknown whether the test is voluntary or compulsory and at what stage it is completed during a student's study.

\section{IL training.}

Predominantly the results show that IL training is provided to students. Furthermore 29 universities do offer it to both students and staff as Webber and Johnston (2003) point out an information literate institution requires that all levels are literate. If $15 \%$ of universities embed IL into their courses, then it is essential that faculty staff are all receiving training if they are responsible for delivering the content to students.

Studies have been undertaken over the years which question the optimal way in which IL skills be taught. The key issues have been integrating IL into the curricula and the significance of the relationship between the subject / liaison librarian and faculty (Booth and Fabian, 2002; Bruce, 2001), both of which can affect the success rates of the training delivered. In our study, most of the website content relating to the promotion of IL training is centred on information seeking, citing and referencing. Further investigation would be necessary to establish whether the other more complex skills (often referred to as higher order skills) including the critical analysis of texts to create an annotated bibliography (Gallacher, 2009), are taught through one-to-one sessions or possibly embedded and taught within the context of the subject of the university courses.

Similarly, further investigation would be necessary to understand why the results show that 21 institutions do not appear to be offering IL training. There may be good reason for this, one being a wariness on the libraries behalf of making the resources publically available on their website. Independent studies conducted by Graham and Secker (2012) and Appleyard (2012) which looked into the creation and sharing of resources amongst LIS 
professionals, including IL resources, found that most respondents preferred to use existing material before spending time creating their own. There were a number of websites which provided links to existing IL programmes offered by other institutions, such as the Virtual Training Suite (Dawson, 2001), Cardiff University's Information Literacy Resource Bank and Project $Q$ by Southampton University. Where resources had been created, respondents commented that they would be reluctant to make them public due to uncertainty with copyright issues, plus some didn't want others using their work. Further investigation into the extent and type of IL training in UK universities may address some of these 'unknowns' in present survey.

\section{IL promotion and student satisfaction with the library service.}

Although many attempts were made to find a relationship between the website score and the THE student satisfaction score for the library, no definitive patterns or results emerged. Although it is perhaps of interest to note that with the exception of the University of South Wales, all the other universities who ranked the highest positions for the THE library satisfaction and website score were traditional universities. If we are to adopt the clear guidance of the Seven Pillars model to underpin the universities commitment to IL, the fact that SCONUL's 2009 survey (Gallacher, 2009) showed that the majority of those using the Seven Pillars model were new universities, suggests that the one question on library satisfaction in the THE survey is not enough to relate to the IL of the library service.

The way forward would be to have specific IL questions in student surveys so that the many roles that an academic library undertakes are not being simplified into an overall satisfaction with the library service. The National Survey of Student Engagement (NSSE) partnered with college and university librarians in America and Canada in 2013, so that an IL module for the 2014 undergraduate survey could be included. The overarching purpose was to investigate student engagement in activities that develop IL skills (Fosnacht, 2014). There were three sections in the module. Firstly, questions which enquired about the frequency with which students engaged in activities to develop IL skills. The second stage focused on how well instructors promoted the proper use of information. The final question looked to assess whether the students college experience had improved their information abilities (Fosnacht, 2014). Data from a survey of this nature would provide IL instructors and 
universities with more relevant information and could also be used to investigate the relationship between IL provision and student satisfaction with the library service.

\section{Conclusions and Recommendations}

The study has provided a valuable insight into promotion of and engagement with IL in UK universities through the important channel of the university website. Whilst this study offers important insights, the extent to which its findings provide a complete picture of IL may be limited. There are many reasons why this may be the case, including practitioners being protective of their resources and not wanting them being used by the general public or other institutions (Graham and Secker, 2012). Also, some perceive that a website is a marketing and sales tool to entice prospective students and as a result will not use it as a learning or information tool for existing students, therefore any IL information or training resources will not be seen until they login. This does however contradict with the suggestion that for IL to be successful it requires integration at all levels of an institution particularly support from top management, therefore meaning that even if the IL training does not appear on the website because of it being a sales tool, IL would still be included within the mission statement, visions or strategic plans as these are available on every university website.

This study has shown that in the ten years since Sheila Corrall's study of UK university websites, there has been no significant evidence that the public information relating to IL has increased, and it is still the case that 'remarkably few library or information services included explicit commitments to IL in formal mission statements'. If academic libraries expect to be perceived as major advocates for and providers of IL instruction, they need to be much more proactive about promoting information literacy through their websites. Furthermore, it would seem that the collaboration in America based on a common IL model and other joint initiatives offers an interesting model. The other agenda for further development is in relation to understanding and responding to the different aspects of information behaviour (and not simply focussing on searching and citation) and linking training and assessment more closely to stage in the curriculum including the transition to postgraduate study and the workplace. This will only be achieved by collaborative innovations, typically discipline-related, that involve co-operation with academics. Taking this wider perspective on information behaviour will also facilitate understanding and 
development of IL initiatives that take into account the wider context of student information behaviour in today's mobile, digital environment.

The current authors are continuing their research into IL with a survey of academic librarians, which will offer a wider range of insights in IL policy and practice in UK university libraries, and provide the opportunity to compare the 'reality' with the 'rhetoric'.

\section{References}

American Library Association. (2016), “ACRL Framework for Information Literacy for Higher Education", available at: http://www.ala.org/acrl/standards/ilframework (accessed 12 August 2016).

Andretta, S. (2005), Information Literacy: A Practioner's Guide, Chandos Publishing, Oxford. Andretta, S. (2006), "Information Literacy: The New “Pedagogy of the Question", Walton, G. and Pope, A., Information Literacy: Recognising the Need, Chandos Publishing, Oxford.

Appleyard, S. (2012), "Sharing and re-use of information literacy resources across higher education libraries in the United Kingdom: a student's view". Journal of Information Literacy, Vol. 6 No. 2, pp. 143-146.

Ariew, S. (2014), "How We Got Here: A historical look at the academic teaching library and the role of the teaching librarian". Communications in Information Literacy, Vol. 8 No. 2, pp. 208-224.

Badke, W. (2014), "Who owns information literacy?" Online Searcher, Vol. 38 No. 4, pp. 6870.

Bawden, D. and Robinson, L. (2009), "The dark side of information: Overload, anxiety and other paradoxes and pathologies". Journal of Information Science, Vol. 35 No. 2, pp. 180-191.

Belshaw, D. A. J. (2011), "What is 'digital literacy'?", available at: http://neverendingthesis.com/doug-belshaw-edd-thesis-final.pdf (accessed 13 March 2015).

Bent, M., Higgins, S. and Brettell, S. (2006), "Developing a Community of Practice: The Newcastle Information Literacy Project", Walton, G. and Pope, A., Information Literacy: Recognising the Need, Chandos Publishing, Oxford. 
Booth, A. and Fabian, C. A. (2002), "Collaborating to advance curriculum-based information literacy initiatives". Journal of Library Administration, Vol 36 No. 1/2, pp. 123-142.

Bruce, C. (2001), "Faculty-librarian partnerships in Australian higher education: critical dimensions". Reference Services Review, Vol. 29 No. 2, pp. 106-115.

Bryman, A. and Bell, E. (2015), Business Research Methods, $4^{\text {th }}$ Ed., Oxford University Press, Oxford.

Cameron, L., Wise, S. and Lottridge, S. (2007), "The Development and Validation of the Information Literacy Test". College \& Research Libraries, Vol. 68 No. 3, pp 229-236.

Catts, R. (2010), “UNESCO Information Literacy Indicators: Validation Report", available at: http://www.unesco.org/new/fileadmin/MULTIMEDIA/HO/Cl/Cl/pdf/information_liter acy_indicators_validation_report_ralph_catts_en.pdf (accessed 12 January 2015).

Chen, K. and Lin, P. (2011), "Information literacy in university library user education". Aslib Proceedings: New Information Perspectives, Vol. 63 No. 4, pp. 399-418.

CILIP. (2014), "IL Group: Definitions”, available at:

http://www.informationliteracy.org.uk/definitions/definitions-of-il/ (accessed 12 September 2014).

Cope, J. and Sanbria, J. E. (2014), “Do We Speak the Same Language? A Study of Faculty Perceptions of Information Literacy", Libraries and the Academy, Vol. 14 No 4, pp. 475-502.

Corrall, S. (2007), "Benchmarking strategic engagement with information literacy in higher education: towards a working model", Information Research, Vol. 12 No. 4, paper 328, available at: http://www.informationr.net/ir/12-4/paper328.html. (accessed 9 March 2015).

Educause Center for Applied Research. (2011), “ECAR National study of undergraduate students and information technology, 2011", available at: https://library.educause.edu/resources/2011/10/ecar-national-study-ofundergraduate-students-and-information-technology-2011-report (accessed 26 March 2015).

Fosnacht, K. (2014), "Information Literacy and NSSE: Introducing the Experiences with Information Literacy Module". College \& Research Libraries News, Vol. 75 No.9, pp. 490-500. 
Gallacher, C. (2009), “Use of SCONUL's 7 Pillar Model for Information Literacy: Findings of a Study of SCONUL institutions $2008-2009 "$, available at: http://www.sconul.ac.uk/sites/default/files/documents/Use_seven_pillars_study_20 09.pdf (accessed 5 July 2016).

Godwin, P. (2003), Information literacy, but at what level? Information and IT literacy: Enabling learning in the $21^{\text {st }}$ century, Facet Publishing, London.

Goldstein, S. (2015), “Perceptions of the SCONUL Seven Pillars of Information Literacy: A brief review", available at: http://www.sconul.ac.uk/sites/default/files/documents/Seven\%20Pillars\%20Review \%202015.pdf (accessed 5 March 2016).

Goodall, D. and Pattern, D. (2011), “Academic library non/low use and undergraduate achievement". Library Management, Vol. 32 No.3, pp. 159-170.

Graham, N. and Secker, J. (2012), "Librarian, Information Literacy and Open Educational Resources", available at: http://deliopenfiles.wordpress.com/2012/04/findingssharingoers_reportfinal1.pdf (accessed 12 August 2016).

Grassian, E. S. and Kaplowitz, J. R. (2009), Information Literacy Instruction Theory and Practice: $2^{\text {nd }}$ Ed., Neal-Schuman, New York.

Gross, M. \& Latham, D. (2012), "What's skill got to do with it?: Information literacy skills and self-views of ability among first-year college students". Journal of the American Society for Information Science, Vol. 63 No. 3, pp. 574-583.

Haddow, G. (2013), "Academic library use and student retention: A quantitative analysis". Library \& Information Science Research, Vol. 35 No.2, pp. 127-136.

Hepworth, M. (1999), "A study of Undergraduate Information Literacy and Skills: the inclusion of information literacy and skills in the undergraduate curriculum", Proceedings of the $65^{\text {th }}$ IFLA Council and General Conference, Bangkok, August 20-28, 1999, The Hague, IFLA, 1999, available at: www.ifla.org/IV/ifla65/papers/107124e.htm (accessed 5 August 2016).

Herman, E. and Nicholas, D. (2010), "The information enfranchisement of the digital consumer". ASLIB Proceedings, Vol. 62 No. 3, pp. 245-260.

Higher Education Funding Council for England. (2010), “Higher Education Funding Council for England National student survey: Findings and trends: 2006-2009 Higher 
Education Funding Council for England", available at:

http://hefce.ac.uk/pubs/hefce/2010/10_18/(accessed 12 August 2016).

Koltay, T., Spiranec, S. and Karvalics, L. Z. (2015), "The Shift of Information Literacy Towards Research 2.0". The Journal of Academic Librarianship, Vol. 41, pp. 87-93.

Kuh, G. D. and Gonyea, R. M. (2003), "The role of the academic library in promoting student engagement in learning". College \& Research Libraries, Vol. 64 No.4, pp. 256-282.

Lau, J. (2006), "IFLA: Guidelines on Information Literacy for Lifelong Learning", available at: http://www.ifla.org/publications/guidelines-on-information-literacy-for-lifelonglearning (accessed 12 November 2014).

Library and Information Commission. (1997), "New Library: The People's Network", (2000b), 'Investigation of Partnership Models between Libraries and Cable Based Communication Providers', LIC Research Report No: 44, London.

Lloyd, A. (2010), Information Literacy Landscapes: Information literacy in education, workplace and everyday contexts, Chandos Publishing, Oxford.

Madden, R. (2014), "Information behaviour of humanities PhDs on an information literacy course". Reference Services Review, Vol. 42 No.1, pp. 90-107.

Mayer, A. K., Peter, J., Leichner, N. and Krampen, G. (2015), “One Size Doesn't Fit All Effectiveness and Subjective Evaluations of Adaptable Information Literacy Instruction". CCIS, Vol. 552, pp. 283-292.

McGuinness, C. (2003), "Attitudes of academics to the library's role in information literacy education", Martin, A. Information and IT literacy: Enabling learning in the $21^{\text {st }}$ century, Facet Publishing, London.

McGuinness, C. (2006), "What faculty think - exploring the barriers to information literacy development in undergraduate education". The Journal of Academic Librarianship, Vol. 32 No.6, pp. 573-582.

McKinney, P., Jones, M. and Turkington, S. (2011), "Information literacy through inquiry: A Level One psychology module at the University of Sheffield". Aslib Proceedings: New Information Perspectives, Vol. 63 No. 2/3, pp.221-240.

Mery, Y., Newby, J. and Peng, K. (2012), "Why one-shot information literacy sessions are not the future of instruction: a case for online credit courses". Coll. Res. Library. Vol. 73, pp. 366-377. 
National Union of Students. (2012), "Student Experience Research", available at: http://www.qaa.ac.uk/en/Publications/Documents/Student-Experience-Research-12Part-1.pdf (accessed 28 August 2016).

Peters, J., Hathaway, D. and Bragan-Turner, D. (2003), “Does discipline matter?” Martin, A. Information and IT literacy: Enabling learning in the $21^{\text {st }}$ century, Facet Publishing, London.

Research Information Network. (2008), "Mind the skills gap: information-handling training for researchers", available at: http://www.rin.ac.uk/system/files/attachments/Mindskills-gap-report.pdf (accessed 18 November 2014).

Saunders, L. (2012), "Faculty perspectives on information literacy as a student learning outcome". The Journal of Academic Librarianship, Vol. 38 No. 4, pp. 226-236.

Secker, J. and Coonan, E. (2011), “A New Curriculum for Information Literacy: Curriculum and Supporting Documents", available at: http://ccfil.pbworks.com/f/ANCIL_final.pdf (accessed 28 September 2014).

SCONUL. (2011), "SCONUL Seven Pillars of Information Literacy: Core Model for Higher Education", available at: http://www.sconul.ac.uk/groups/information_literacy/seven_pillars.html (accessed 28 September 2014).

Shenton, A. K. and Fitzgibbons, M. (2010), "Making information literacy relevant". Library Review, Vol. 59 No. 3, pp. 165-174.

Smith, J. K., Given. L., Julien, H., Ouellette, D. and DeLong, K. (2013), "Information literacy proficiency: assessing the gap in high school students' readiness for undergraduate academic work". Library \& Information Science Research, Vol. 35, pp. 88-96.

Stubbings, R. and Franklin, G. (2005), "More to life than Google: A journey for PhD students". Journal of eLiteracy, Vol. 2, pp. 93-103.

Town, J. S. (2003), "Information literacy: definition, measurement, impact". Martin, A. Information and IT literacy: Enabling learning in the $21^{\text {st }}$ century, Facet Publishing, London.

Universities UK. (2015), “Our Members”, available at: http://www.universitiesuk.ac.uk/about/Pages/member-institutions.aspx (accessed 7 January 2015). 
Virkus, S. and Mandre, S. (2015), "Information Literacy, Leadership and Management". CCIS, Vol. 552, pp. 80-89.

Walsh, A. (2009, "Information Literacy Assessment: Where do we start?" Journal of Librarianship and Information Science, Vol. 41 no. 1, pp. 19-28.

Wang, L. (2011), "An information literacy integration model and its application in higher education". Reference Services Review, Vol. 39 No. 4, pp. 703-720.

Webber, S. and Johnston, B. (2003), “Assessment for information literacy: vision and reality", Martin, A. Information and IT literacy: Enabling learning in the $21^{\text {st }}$ century, Facet Publishing, London.

Webber, S. and Johnston, B. (2006), "Working towards the Information Literate University", Walton, G. and Pope, A., Information Literacy: Recognising the Need, Chandos Publishing, Oxford.

Wilder, S. (2005), "Information Literacy makes all the wrong assumptions". The Chronicle of Higher Education, Vol. 51 No. 18, B13.

Wise, S. L., Cameron, L., Yang, S. and Davis, S. (2005), "Information Literacy Test: Test Development and Administration Manual", Harrisonburg, Institute for ComputerBased Assessment; Centre for Assessment \& Research Studies, James Madison University.

Zurkowski, P. G. (1974), The Information Service Environment Relationship and Priorities, Related Paper No. 5. National Commission on Libraries and Information Science, Washington, DC. 
Appendix 1

\section{Coding Schedule}

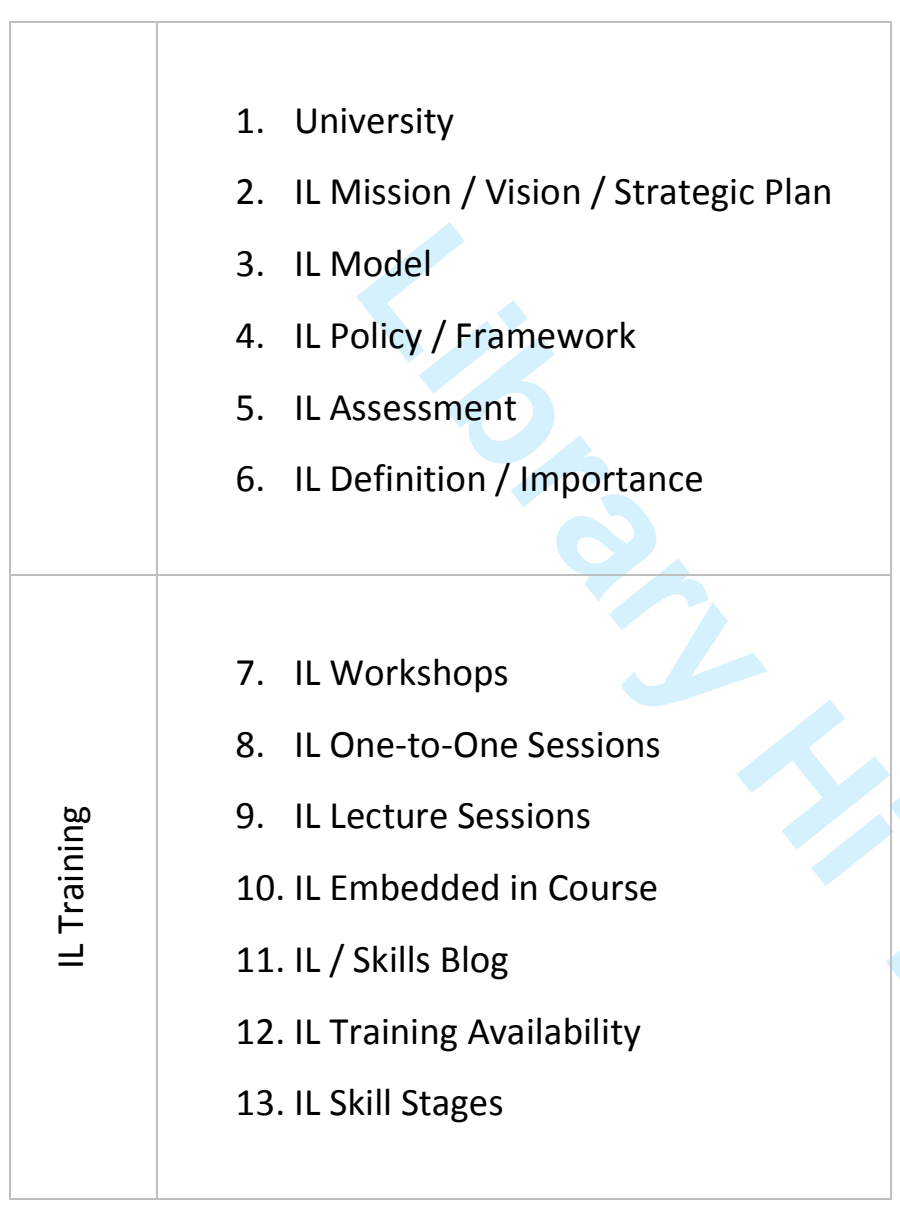

\section{Coding Manual}

1. University

As per the alphabetical ordered list on the Universities UK website, each university was awarded a number in sequential order.

2. IL Mission / Vision / Strategic Plan

$$
\begin{aligned}
& 0=\mathrm{IL} \text { not included in the mission / vision / strategic plan } \\
& 1=\mathrm{IL} \text { is included in the university library's mission / vision / strategic plan } \\
& 2=\mathrm{IL} \text { is included in the university's mission / vision / strategic plan }
\end{aligned}
$$




\section{IL Model}

$$
\begin{aligned}
& 0=\text { No model } \\
& 1=\text { Using a model but details are not in a prominent place } \\
& 2=\text { Using a model and details are in a prominent place }
\end{aligned}
$$

4. IL Policy / Framework

$$
\begin{aligned}
& 0=\text { No policy } / \text { framework } \\
& 1=\text { Have a policy } / \text { framework but details are not in a prominent place } \\
& 2=\text { Have a policy } / \text { framework and details are in a prominent place }
\end{aligned}
$$

5. IL Assessment

$$
\begin{aligned}
& 0=\text { No assessment } \\
& 1=\text { Have an assessment }
\end{aligned}
$$

6. IL Definition / Importance

$$
\begin{aligned}
& 0=\text { No definition } / \text { importance } \\
& 1=\text { Define IL and } / \text { or its importance on website }
\end{aligned}
$$

IL Training

7. IL Workshops

$$
\begin{aligned}
& 0=\text { No workshops } \\
& 1=\text { A limited variety of workshops available } \\
& 2=\text { A wide variety of workshops available }
\end{aligned}
$$

8. IL One-to-One Sessions

$$
\begin{aligned}
& 0=\text { No one-to-one sessions } \\
& 1=\text { Appointments or drop-in sessions available } \\
& 2=\text { Appointments and drop-in sessions available }
\end{aligned}
$$

9. IL Lecture Sessions

$$
\begin{aligned}
& 0=\text { No lecture sessions } \\
& 1=\text { Lecture sessions available }
\end{aligned}
$$

10. IL Embedded in Course

$$
\begin{aligned}
& 0=\text { Not embedded in any courses } \\
& 1=\text { Embedded in course(s) }
\end{aligned}
$$

11. IL / Skills Blog

$$
0=\text { No blog }
$$$$
1 \text { = Blog available }
$$ 
12. IL Training Availability

$$
\begin{aligned}
& 0=\text { No training available or not clear who it is intended for } \\
& 1=\text { Training available for students or staff only } \\
& 2=\text { Training available for students and staff }
\end{aligned}
$$

13. IL Skill Stages

$0=$ No training available

1 = Training available but only covers one or a few stages of IL (e.g. information seeking)

$2=$ Training available and covers most $/$ all stages of IL 